\title{
Reading skill development through CLIL Methodology
}

\section{Desarrollo de la capacidad de lectura a través de la metodología CLIL}

Gabriela Margarita Ramírez Casco. ${ }^{1}$ \& Jazmina Ivonne Mena Mayorga. ${ }^{2}$

\begin{abstract}
.
DOI: https://doi.org/10.33262/concienciadigital.v4i3.1702

Introduction. In the mid-90s, as a result of the language policies adopted in Europe to improve the language skills of its citizens, a new approach to language learning emerged, this was named, Content Integrated Learning and Foreign Languages (CLIL). With the same vision, within the changes made in its educational policy, since 2016 Ecuador implements this approach in its foreign language curriculum. Objective. The objective of this work was to provide evidence on the effectiveness of Content and Language Integrated Learning (CLIL) in the acquisition of reading competence compared to the traditional learning of English as a foreign language (EFL) in the first year of Bachillerato at Unidad Educativa Riobamba. Methodology. The study was carried out based on a quantitative method, quasi experimental design and it was applied in two moments: pre and post- test. In order to determine the statistical differences in the reading comprehension process between the two groups of students, CLIL reading texts were applied to a population of 60 students, which 30 students represented the control group and all the other remaining students were the experimental group. The control group was evaluated after using the textbook as the only class teaching material and, the experimental group, was evaluated after receiving CLIL classes using its corresponding materials. Results. The results indicated that students in the experimental group showed at the end of the project, a significant development in reading comprehension and

\footnotetext{
${ }^{1}$ U.E Riobamba, Riobamba, Ecuador. Gabriela.m.ramirez.c@pucesa.edu.ec, http://orcid.org/0000-00021696-3587

${ }^{2}$ Pontificia Universidad Católica del Ecuador - Sede Ambato, Maestría en Pedagogía del Inglés como Lengua Extranjera, Tungurahua, Ecuador, jazmin_menamayorga@hotmail.com, http://orcid.org/00000002-5073-5967
} 
vocabulary. Conclusion. Therefore, through this research it was determined that the use of CLIL texts directly influenced the development of reading comprehension and requires teachers to start using this approach.

Keywords: Content and Language Integrated Learning, reading comprehension, vocabulary.

\section{Resumen}

Introducción. A mediados de los años 90, como resultado de las políticas lingüísticas adoptadas en Europa para mejorar las habilidades lingüísticas de sus ciudadanos, surgió un nuevo enfoque para el aprendizaje de idiomas, este fue denominado Aprendizaje Integrado de Contenidos y Lenguas Extranjeras (CLIL). Con la misma visión, dentro de los cambios realizados en su política educativa, desde 2016 Ecuador implementa este enfoque en su currículo de lenguas extranjeras. Objetivo. El objetivo de este trabajo fue evidenciar la efectividad del Aprendizaje Integrado de Contenidos y Lengua (CLIL) en el desarrollo de la comprensión lectora en contraste con el aprendizaje tradicional de inglés como lengua extranjera (EFL) en el primer año de Bachillerato de la Unidad Educativa Riobamba. Metodología. El estudio basado en un método cuantitativo de diseño cuasi experimental se lo aplicó en dos momentos: pre y pos-test. Con el propósito de identificar las diferencias estadísticas en el proceso de comprensión lectora entre los dos grupos de estudiantes, se aplicaron textos de lectura CLIL a una población de 60 estudiantes, de los cuales 30 estudiantes representaron el grupo de control y los otros 30 conformaron el grupo experimental. El grupo de control fue evaluado luego de utilizar el libro de texto como único material de clase y, el grupo experimental, fue evaluado luego de recibir las clases CLIL utilizando sus correspondientes materiales. Resultados. Los resultados mostraron que, al final del proyecto, los estudiantes del grupo experimental lograron alcanzar un desarrollo significativo en comprensión lectora y vocabulario. Conclusión. Así entonces, a través de este trabajo de investigación se determinó que el uso de textos CLIL influyó directamente en el desarrollo de la comprensión lectora y requiere que los docentes comiencen a utilizar este enfoque.

Palabras clave: Aprendizaje integrado de contenido y lenguaje, comprensión lectora, vocabulario.

\section{Introduction.}

In the mid-90s, within European language policies, the Content and Language Integrated Learning (CLIL) model emerged as a proposal to improve linguistic competence in foreign or additional languages in citizenship. From here on, an idea focused on the development of multilingualism with the protection of identity languages begins to be sought. Something that seemed contradictory in origin becomes a sine qua non of what European language policy is, thus in this context, plus the contribution of technology, which is creating the most multilingual generation in history, draws a scenario of what 
that is clearly happening today, the need for multilingual profiles but at the same time the need to protect those languages that are in danger of extinction.

With the same vision, within the changes in educational policy that arise in Ecuador in 2016, a new foreign language curriculum was implemented which responds to the needs of the Ecuadorian reality. Between the basic principles of the curricular proposal, Content and Language Integrated Learning (CLIL) is established as a model used to integrate language learning linked to cultural and cognitive aspects, thus, the acquisition of this language will be the engine for the development of students (Ministry of Education, 2016).

As stated, this multifaceted approach improves the level of proficiency that students have in English. There are a large number of studies focused mainly on a secondary education context in which the benefits of CLIL are reported, but there are aspects in these findings that are not conclusive, such as the classification of language skills that are favorably affected or not by this approach. This situation motivated us to inquire about the results of the implementation of this approach, and specifically with regard to reading skills since this is a topic that motivates discussion because many of educational problems in the country are attributed to it. This is reasonable, since Ecuador is one of the countries in the region where fewer books are read per year (Matamoros. 2019)

Considering that reading is the most important instrument in the academic environment (Khatib, 2012) and consequently it is one of the aspects that must be achieved by students in order to develop other skills (Tiara 2018), it is necessary to know about the results of the implementation of this approach, specifically with regard to the aforementioned skill, in our educational environment. Analyzing the results of the instruments applied to the subjects, in the current educational reality, it will be possible to define the factors that influence the development of reading skills in a CLIL context, also allowing the necessary corrections to be made at the time of their application and, thus, the student s ' willingness to better development in their academic work in pursuit of their goals, thus avoiding academic failure (Lamas, 2008).

\section{Methodology.}

\section{Literature Review}

Content and Language Integrated Learning (CLIL) has to do with the teaching of subjects such as: Science, History, Arts, Geography, Physical Education and, somewhat discussed, Mathematics to students through a foreign or additional language. David Marsh and Anne Maljers began their promotion in 1994 (Marsh, 2000). The approach integrates contents of general subjects motivating the learner with phrases such as "You can do it." In this way, students are exposed to processes as close as possible to the natural way in which they learn other academic content (Marsh, 2012) 
CLIL model poses challenges for the teacher. Thus, there is a need for teachers to be willing to assume responsibility for the development of language awareness (Mehisto, 2008). Another challenge is related to production levels since these can be highly variable depending on the thinking maturity of each student. Its evolution requires a space of interaction to unite the understanding capacity of the subjects by students. This takes the bases in what Baker (2009) affirms regarding that, the person makes explanations of a topic, then the contextual construction and deconstruction of concepts appear and arise as an interactive action reaching high levels of complexity (Llinares and Morton 2010).

This approach has to do with situations where subjects, or parts of subjects, are taught through a foreign language for dual purposes; content learning and simultaneous foreign language learning. According to Baker (2009), this method leads to activate the mental processes of contextual construction and concept construction interactively, they move away from simple description since the class requires materials loaded with details that facilitate the understanding of the problem and the proposal of solutions (Llinares and Morton 2010). It is about the practical and natural use of a foreign language that must surround the learner while acquiring knowledge about another subject.

\section{The principles of the CLIL method}

These four principles are essential for CLIL. They should be used as the framework to create and deliver successful lessons:

Communication: Communication has to do with students using the L2 to communicate their thoughts, attitudes, opinions, and others related to the content of the lesson. Both speech and writing are emphasized as students "learn to use language and use language to learn" (Mehisto, Marsh \& Frigols, 2008).

Culture: Culture, also known as community and citizenship, has to do with the learning community of a class and school and, more extensively, to local and global cultures. Learners are encouraged and committed to understand themselves as citizens of the world and to understand both their own culture and others. The ultimate purpose is to promote international awareness and understanding.

Cognition: This concerns the critical thinking skills students use to engage and understand the content of a course, to solve problems, and to reflect on their learning.

Content: Content refers to the topic or topics of the lesson or course. Examples of different content areas include history, science, math, geography, or others.

CLIL implementation offers numerous advantages but teachers who desire to be successful in CLIL classrooms should consider the main principles (Mehisto et al., 2008):

1. Authenticity: The use of authentic materials, authentic case and authentic content from the real world such as daily newspapers, brochures, flight attendance in airline business courses/topics. 
2. Multiple focus: The use of a variety of activities helps develop the students' several skills at the same time. Automatic learning will occur.

3. Active learning: The students are active in both the preparation and presentation stages. The teacher has to encourage the students to take a role in all steps of learning. Participation can activate active learning.

4. Safe learning environment: Familiar classroom setting and peer participation help the students feel safe and learn new things without less worry.

5. Scaffolding: The teacher is a facilitator and peers are consultants through class discussion. The teacher has to be ready to help the students all the time and also to encourage them to be good peers in helping each other to learn.

\section{Public Policy for the teaching of English learning in Ecuador}

The Professional Teacher Performance through its standards, allows us to implement the characteristics and practices of a teacher accredited as such, who, in addition to having mastery of the specific area, shows other characteristics that strengthen his/her performance, such as the use of innovative and varied pedagogy, permanent updating, good relationship with students and parents, professional ethics, among others. These standards refer to all these elements and allow the teacher to frame their performance within clear parameters. The purpose of the Professional Teacher Performance standards is to promote teaching that allows all Ecuadorian students to achieve their profiles declared by the National Curriculum for Basic General Education and for the Bachillerato.

Domain 1 - Language: This domain is related to the knowledge about the English language that teachers should know. In order to better understand this domain, 2 subdivisions are made. The first is related to the "Structure of English and Communication", where teachers must master certain topics such as: Phonology, Morphology, Pragmatic, Syntax and Semantics.

All this knowledge must be used to develop the four skills (listening, speaking, reading and writing) in the students. Likewise, professionals in this area must have extensive knowledge of theories and research related to the acquisition of English.

Domain 2 - Culture: As each language is always strongly affected by the culture of the country of origin, the culture of students attempting to learn a second language cannot be underestimated. In this way, teachers must have knowledge related to the culture of the language to be taught and about the cultural identity of the students. It is also important to use resources to better understand our culture, such as the culture of a foreign language. All this must be done with the aim of mitigating false stereotypes and strengthening links between the two countries, since it will be an efficient way to achieve meaningful learning.

Domain 3 - Curriculum Development: This domain is related to planning, implementation and management strategies of English. In addition, teachers must know about teaching 
strategies and adaptations of the curriculum. Everything with the aim of satisfying the needs and interests of their pupils. On the other hand, their annual plans, units and skills should be based on the students' competencies, learning styles, educational experiences and knowledge.

Domain 4 - Assessment: Teachers have a clear understanding of assessment concepts and processes. Similarly, they use the necessary resources to provide adequate reinforcement after each assessment.

Domain 5- Professionalism and Ethical Commitment: As in any profession, teachers must not stop investigating, analyzing and applying new techniques, methods and knowledge. On the one hand, teachers must demonstrate knowledge of history, research, public education policies, and up-to-date practices in the field of education. Also, they should participate in workshops, seminars and any other opportunity to strengthen their teaching skills and acquire new ones. Finally, those professionals must promote the practice of values and laws protected in the Constitution of Ecuador.

\section{Reading and CLIL}

The essence of CLIL is that it is about teaching and learning content and, language is the key to a more complete understanding of the subject (Mehisto et al., 2008). When the word comprehension comes out, it refers to reading comprehension, and it is well known that reading is a term frequently used in the teaching and learning process, but to date there is no consensus on what it means exactly (Straková \& Sepešiová, 2015), however it is necessary to detail its importance in the process of learning a foreign or additional language.

It is said that reading can help improve other language skills of a language because of all the information and structures it provides. In relation to this, Goodman (1996) stated that reading is a psycholinguistic guessing game because it is a procedure of teaching grammar, vocabulary and pronunciation. With this argument, there is no doubt that reading can be used as a tool to improve other aspects of the language and its skills. In addition, writers such as Mikulecky \& Jeffries (2005) stated that reading is one of the most important skills in teaching a second language because it promotes imagination and curiosity, increments lexical competence, motivates readers to get new experiences and build meaningful knowledge.

It is important to mentioning that reading is an intentional process that demands strategies to construct the meaning of the text; consequently, including strategies in its implementation is essential, as they contribute to the acquisition of vocabulary and facilitate understanding. When we read, we make our own interpretations and create meaning based on our prior knowledge, experiences, and educational background, which means that a text cannot be understood by two people in the same way (Goodman, 1970). 


\section{Reading Comprehension.}

Whoever has an efficient reading comprehension implies that he/she also has a social and educational background of the individual and the use of reading strategies. In this sense, Smith (1982) mentioned that reading comprehension is the process of making sense of the world by means of the relation between previous antecedents and the new information. If the readers do not have knowledge or experience on a topic, there will be no understanding of the text, which is the ultimate goal of reading (Winch et al., 2006). Thus, if the text is not understood, the reading process is purposeless.

In relation to the process of understanding a text, Nuttall (1996) proposes six levels that could be considered: (a) Literal comprehension, which is the superficial meaning that a reader gives to the text based on vocabulary, places, dates and times; (b) reorganization, where students can answer specific questions about the text concerning numbers, names among others; (c) inference, there students answer questions that go beyond simple, explicit and literal information; (d) predictions, have to do with evaluating one's prior knowledge by means of answering questions about the text. At this point, readers can predict what will happen next; (e) evaluation, it happens when students become aware about the quantity they have learned after this process. To sum up, comprehensive reading is a complex process that goes beyond simply understanding of letters and symbols.

\section{Metodology.}

This study was carried out based on a quantitative approach. Firstly, the problem was set, specified and limited at the beginning of the study. Secondly, the hypothesis was previously established ergo, this investigation had a hypothesis before data gathering. Finally, the data gathering was measurable and the results were analyzed through a statistical process. The following research was carried out by the quasi-experimental design. It was applied to two groups: control and experimental. Both groups of similar characteristics. At the end of the intervention plan, the results were compared and analyzed.

This work started with a descriptive level of research, each variable independently through the literature presented in the theoretical framework were analyzed. The two variables were detected, so that, there were data in which this study was based on. Additional reason why this research started with this level of research was that the results of the pre and post-tests were associated and carefully analyzed.

In addition, this investigation got to a second stage, this was the correlational research. Thus, it determined if the independent variable, CLIL texts, influences the dependent variable, reading comprehension. This level of study allowed the researcher to know if there was any relation between the two variables. The population of this study were sixty (60) students. They were students of the First year of Bachillerato, classes "E" and " $\mathrm{H}$ " at Unidad Educativa Riobamba, being " $E$ " the experimental group, and " $\mathrm{H}$ " the control group. There were thirty students (30) in the experimental group and thirty students (30) 
students in the control. A sample was not necessary due to the fact that the population size was small.

Both groups took the pre and post-test and post-test but, only the experimental group experienced learning by reading comprehension using CLIL texts presented in the intervention plan. The researcher employed some instruments for the effectiveness of this research, these were: pre-test, post-test and reading comprehension rubric

The pre-test was planned and designed in order to measure the dependent variable and to know the level of the students' reading comprehension. It is important to mention that the instruments were validated by experts in the area of languages. It had four parts and fourty items that permitted to measure reading comprehension and vocabulary. The students had 90 minutes to read the texts, analyze them and answer questions. It was graded by means of a rubric.

Post-test was designed with very similar questions to the pre-test. It allowed to measure reading comprehension and vocabulary. It lasted 90 minutes to read the texts, analyze them and answer corresponding questions. Additionally, it went along with the objectives and operationalization of the dependent variable of this research.

Due to the fact that the dependent variable of this research is the reading comprehension skill, a rubric was used. It allowed measuring each participant's performance on the reading comprehension, vocabulary, general understanding and detailed understanding. Through the rubric, each participant has a grade in both the pretest and posttest. This grade permitted to compare the results of the pre-test and post-test.

\section{Results.}

Pre-test control group and experimental group

\begin{tabular}{|c|c|c|c|c|c|c|c|}
\hline \multicolumn{4}{|c|}{ Pre-test control group } & \multicolumn{4}{|c|}{ Pre-test experimental group } \\
\hline Student & Comprehension & Vocabulary & Total & Student & Comprehension & Vocabulary & Total \\
\hline 1 & 2 & 2 & 4 & 1 & 3 & 2 & 5 \\
\hline 2 & 2 & 2 & 4 & 2 & 3 & 3 & 6 \\
\hline 3 & 2 & 2 & 4 & 3 & 1 & 2 & 3 \\
\hline 4 & 2 & 2 & 4 & 4 & 1 & 2 & 3 \\
\hline 5 & 2 & 4 & 6 & 5 & 3 & 1 & 4 \\
\hline 6 & 3 & 2 & 5 & 6 & 2 & 2 & 4 \\
\hline 7 & 2 & 2 & 4 & 7 & 3 & 2 & 5 \\
\hline 8 & 3 & 2 & 5 & 8 & 3 & 2 & 5 \\
\hline 9 & 3 & 2 & 5 & 9 & 3 & 2 & 5 \\
\hline 10 & 2 & 2 & 4 & 10 & 3 & 2 & 5 \\
\hline 11 & 3 & 2 & 5 & 11 & 3 & 2 & 5 \\
\hline 12 & 3 & 2 & 5 & 12 & 2 & 2 & 4 \\
\hline 13 & 3 & 2 & 5 & 13 & 2 & 2 & 4 \\
\hline 14 & 3 & 2 & 5 & 14 & 2 & 2 & 4 \\
\hline
\end{tabular}


ISSN: 2600-5859

www.concienciadigital.org

Vol. 4, N³, p. 68-80, julio - septiembre, 2021

\begin{tabular}{cccccccc}
15 & 2 & 2 & 4 & 15 & 2 & 3 & 5 \\
16 & 2 & 2 & 4 & 16 & 2 & 1 & 3 \\
17 & 2 & 2 & 4 & 17 & 2 & 2 & 4 \\
18 & 3 & 2 & 5 & 18 & 2 & 1 & 3 \\
19 & 3 & 2 & 5 & 19 & 3 & 2 & 5 \\
20 & 3 & 2 & 5 & 20 & 3 & 2 & 5 \\
21 & 3 & 2 & 5 & 21 & 3 & 2 & 5 \\
22 & 3 & 2 & 5 & 22 & 3 & 2 & 5 \\
23 & 3 & 2 & 5 & 23 & 3 & 2 & 5 \\
24 & 3 & 2 & 5 & 24 & 3 & 4 & 7 \\
25 & 3 & 2 & 5 & 25 & 3 & 2 & 5 \\
26 & 2 & 2 & 4 & 26 & 3 & 2 & 5 \\
27 & 2 & 2 & 4 & 27 & 3 & 2 & 5 \\
28 & 2 & 2 & 4 & 28 & 3 & 2 & 5 \\
29 & 2 & 2 & 4 & 29 & 2 & 2 & 4 \\
30 & 2 & 2 & 4 & 30 & 3 & 2 & 5 \\
$\mathrm{X}$ & 2.50 & 2.07 & 4.57 & $\mathrm{X}$ & 2.57 & 2.03 & 4.60 \\
\hline
\end{tabular}

Table 1.

Author: Ramírez, G. (2020)

Post-test control group and experimental group

Post-test control group

Post-test experimental group

Student Comprehension Vocabulary Total Student Comprehension Vocabulary Total

\begin{tabular}{|c|c|c|c|c|c|c|c|}
\hline 1 & 5 & 5 & 10 & 1 & 4 & 5 & 9 \\
\hline 2 & 5 & 4 & 9 & 2 & 4 & 5 & 9 \\
\hline 3 & 4 & 5 & 9 & 3 & 4 & 5 & 9 \\
\hline 4 & 5 & 4 & 9 & 4 & 4 & 5 & 9 \\
\hline 5 & 4 & 5 & 9 & 5 & 4 & 5 & 9 \\
\hline 6 & 5 & 4 & 9 & 6 & 5 & 5 & 9 \\
\hline 7 & 5 & 5 & 10 & 7 & 4 & 5 & 9 \\
\hline 8 & 5 & 5 & 10 & 8 & 5 & 4 & 9 \\
\hline 9 & 4 & 5 & 9 & 9 & 4 & 5 & 9 \\
\hline 10 & 4 & 5 & 9 & 10 & 5 & 5 & 9 \\
\hline 11 & 5 & 5 & 10 & 11 & 4 & 5 & 10 \\
\hline 12 & 5 & 5 & 10 & 12 & 5 & 5 & 10 \\
\hline 13 & 5 & 5 & 10 & 13 & 5 & 5 & 10 \\
\hline 14 & 5 & 5 & 10 & 14 & 5 & 5 & 10 \\
\hline 15 & 5 & 5 & 10 & 15 & 5 & 5 & 10 \\
\hline 16 & 4 & 5 & 9 & 16 & 5 & 5 & 10 \\
\hline 17 & 5 & 5 & 10 & 17 & 5 & 5 & 10 \\
\hline 18 & 5 & 5 & 10 & 18 & 5 & 5 & 10 \\
\hline 19 & 4 & 5 & 9 & 19 & 5 & 5 & 10 \\
\hline 20 & 5 & 4 & 9 & 20 & 5 & 5 & 10 \\
\hline 21 & 4 & 5 & 9 & 21 & 5 & 5 & 10 \\
\hline 22 & 5 & 4 & 9 & 22 & 5 & 5 & 10 \\
\hline
\end{tabular}




\begin{tabular}{cccccccc}
23 & 4 & 5 & 9 & 23 & 5 & 5 & 10 \\
24 & 4 & 5 & 9 & 24 & 5 & 5 & 10 \\
25 & 4 & 5 & 9 & 25 & 5 & 5 & 10 \\
26 & 4 & 5 & 9 & 26 & 5 & 5 & 10 \\
27 & 5 & 5 & 10 & 27 & 5 & 5 & 10 \\
28 & 5 & 5 & 10 & 28 & 5 & 5 & 10 \\
29 & 5 & 5 & 10 & 29 & 5 & 5 & 10 \\
30 & 5 & 5 & 10 & 30 & 5 & 5 & 10 \\
$X$ & 4.63 & 4.83 & 9.47 & $\mathrm{X}$ & 4.73 & 4.97 & 9.67 \\
\hline
\end{tabular}

Table 2.

Author: Ramírez, G. (2020)

\begin{tabular}{lc} 
Comprehension & \\
\hline Pre-test control & 2,50 \\
\hline Pre-test experimental & 2,57 \\
Post-test control & 4,63 \\
Post-test experimental & 4,73 \\
\hline $\begin{array}{l}\text { Table 3. } \\
\text { Author: Ramírez, G. (2021) }\end{array}$
\end{tabular}

\section{Analysis and Interpretation}

Question about comprehension in the pre-test, the average of 30 students in the control group was 2,50 and the average of the experimental group in this question was 2,57. These values show that both groups had almost the same average regarding comprehension in the pre-test. Similarly, the average in the post-test of the control group was 4,63 and the average of the experimental group was 4,73 . Thus, these values show that there was an increase of 0.10 after the application process for the average in the experimental group.

\begin{tabular}{lc} 
Vocabulary \\
\hline Pre-test control & 2,07 \\
\hline Pre-test experimental & 2,03 \\
Post-test control & 4,83 \\
Post-test experimental & 4,97 \\
\hline $\begin{array}{l}\text { Table 4. } \\
\text { Author: Ramírez, G. (2020) }\end{array}$
\end{tabular}

\section{Analysis and Interpretation}

Question about vocabulary in the pre-test, average in control group was 2,07 and average of experimental group was 2,03. These values show that both groups had the same average regarding vocabulary in the pre-test. Same way, average of the post-test control was 4,83 and the average of the post-test experimental was 4,97. Subsequently, these 
values show that there was an increase of 0.14 after the application for the average in experimental group.

\section{Conclusions.}

- CLIL texts improve reading comprehension on learners who were studying at the Unidad Educativa Riobamba. The data analysis showed that at the beginning of the course, students started with a specific level on their reading comprehension but after applying CLIL texts in classes their level and grades improved, consequently their reading comprehension was improved.

- It was found that using CLIL as a teaching tool, made students have a favorable development in English reading comprehension. The reason to claim this statement is the improvement in grades and the average that experimental group got in comparison with control group and additionally learners felt motivated and enjoyed classes.

- Finally, CLIL was considered an effective strategy to be applied in classes because of the good grades students got and also because the researcher defined that the relation between CLIL texts and comprehension is based on a better understanding of CLIL texts used.

\section{Bibliographic References.}

Goodman, K. (1970) Reading as a psycholinguistic guessing game.Newark, NJ:International Reading Association.

Goodman, K. (1996).On reading. Portsmouth. NH:Helhenman.

Khatib. M. (2012). Enhancing Reading Comprehension through Short Stories in Iranian EFL Learners. Theory and Practice in Language Studies. Academic Publisher.

Lamas, H. (07 de Julio de 2008). Aprendizaje autorregulado, motivación y rendimiento académico. http://www.scielo.org.pe/scielo.php?pid=S172948272008000100003\&script=sci_arttex

Matamoros, L. (2019). Cuanto se lee en Ecuador.Vistazo.com. https:// www.vistazo.com/seccion/ciencia-y-tecnologia/ciencia/cuanto-se-lee-en ecuador

Marsh, D. (2000). Using Languages to Learn and Learning to Use Languages. An introduction to AICLE for parents and young people. http://archive.ecml.at/mtp2/AICLEmatrix/pdf/1uk.pdf

Marsh, D. (2012). Content and language integrated learning (AICLE): A development trajectory. Córdoba, España: University of Córdoba. 
Mehisto, P. (2008). AICLE Counterweights: Recognising and decreasing disjuncture in AICLE. International AICLE resereach Journal,11(8), 93-119. http://www.icrj.eu/11/article8.html

Mehisto, P., Marsh, D. \& Frigols, M. J. (2008). Uncovering CLIL, content and language integrate learning in bilingual and multilingual education. Oxford: Macmillan.

Mikulecky, B. S., \& Jeffries, L. (2005). Reading power: Reading for pleasure, comprehension skills, thinking skills, reading faster. White Plains, NY: Longman.

Ministerio de Educación del Ecuador (2015). Currículo 2016-2017 para la enseñanzade inglés en Ecuador. http://educacion.gob.ec/wpcontent/uploads/downloads/2016/04/Presentacion-Curriculo.pdf

Nuttall, C. (1996). Teaching reading skills in a foreign language. Oxford, UK:Heinemann.

Smith, F. (1982). Reading. Cambridge University Press.

Straková, Z. \& Sepesiová, M. (2018). CLIL in Reading Programs. University of Presov, Faculty of Arts, Institute of British and American Studies. https://www.researchgate.net/publication/324200905_CLIL_IN_READING_PR OGRAMMES

Tiara, P. ( 2018) The use of Short Story as Materials in Reading. [Tesis Degree, Universitas Islam Indonesia]. https://dspace.uii.ac.id/bitstream/handle/123456789/5391/Thesis\%20final.pdf?se quence $=1 \&$ isAllowed $=\mathrm{y}$

Winch, G., Ross Johnston, R., March, P., Ljungdahl, L. \& Holliday, M. (2006). Literacy: Reading, writing and children's literature (3rd Edn.). Oxford: Oxford University Press.

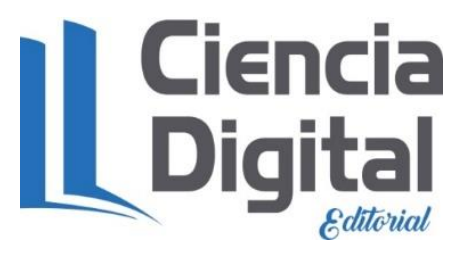




\section{PARA CITAR EL ARTÍCULO INDEXADO.}

Ramírez Casco, G. M., \& Mena Mayorga, J. I. (2021). Reading skill development through CLIL Methodology . ConcienciaDigital, 4(3), 68-80. https://doi.org/10.33262/concienciadigital.v4i3.1702

\section{¿Ciencia}

El artículo que se publica es de exclusiva responsabilidad de los autores y no necesariamente reflejan el pensamiento de la Revista Conciencia Digital.

El artículo queda en propiedad de la revista y, por tanto, su publicación parcial y/o total en otro medio tiene que ser autorizado por el director de la Revista Conciencia Digital.

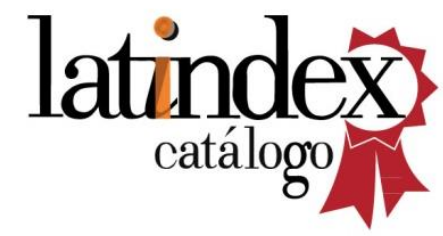

